\title{
PEMIKIRAN POLITIK DALAM TAFSIR FATH AL-QADIR: Pembacaan atas Konsep Ketatanegaraan dalam al-Quran yang Ditulis al-Shawkany
}

\author{
Yusuf Hanafi \\ Jurusan Sastra Arab, Fakultas Sastra, Universitas Negeri Malang. \\ E-mail: sufi rmi@yahoo.com. HP. 081334111537. \\ Diterima tanggal 17 Februari 2012 / Disetujui tanggal 15 April 2012
}

\begin{abstract}
This paper discusses about the political thought in tafsir al qadir written by al-Shawkany. It is written in the paper that in the locus of political life of the state, there is a phenomenon that muslims fell the awkwardness in solving some fundamental problems, such as how to find the right relationship between Islam and politics, how to position of Islamic law in the context of a modern democratic state, and how Islamic law should be understood and practiced. The awkwardness was later implicated in the birth of various types of political experimentation. Islamic tradition of thought in political philosophy did not develop because of political thought are tanght in two different disciplines, namely discipline of Jurisprudence and discipline of philosophy. Ironically, in the tradition of Islamic scholarship that dominates is the discipline of jurisprudence, therefore we can not get out of the paradigm of political theology (political theology).
\end{abstract}

Kata kunci: politik, ketatanegaraan, teologi politik

\section{Pendahuluan}

Terdapat konsensus di sebagian kalangan umat Islam bahwa Nabi Muhammad SAW adalah pemimpin yang harus diteladani, dan masyarakat politik Madinah yang dibangunnya haruslah dijadikan referensi utama. Telah dipahami pula bahwa Muhammad SAW bukan hanya pemimpin agama melainkan juga seorang pemimpin politik. Dalam diri Nabi, dua kekuatan itu telah bersatu-padu. Jika legalitas kepemimpinan agamanya diperoleh dari Allah SWT, maka legitimasi kepemimpinan politiknya didapat dari 
masyarakat pendukungnya. ${ }^{1}$ Tak salah jika kemudian muncul jargon al-Islam din wa siyasah (Islam merupakan agama sekaligus berdimensi politik). ${ }^{2}$

Pada perkembangannya, topik ini menjelma menjadi salah satu diskursus yang kontroversial dan seolah menjadi "beban sejarah" yang sampai detik ini belum tuntas. Timbulnya kontroversi tersebut tidak lepas dari watak ajaran Islam yang sangat elastis dan interpretatif. Harus diakui bahwa umat Islam tidak memiliki konsep ketatanegaraan yang jelas dan kongkret. Masalah inilah yang pada akhirnya menimbulkan penafsiran beragam, baik terhadap nas sendiri maupun terhadap praktik politiknya. Politik Islam tidak bisa dilepaskan dari fenomena sejarah yang polyinterpretable semacam ini. Pada satu sisi, hampir setiap Muslim percaya akan pentingnya penerapan prinsip-prinsip Islam dalam seluruh segmen kehidupan. Sementara pada saat yang sama, karena sifat Islam yang polyinterpretable itu, tidak pernah ada pandangan tunggal mengenai bagaimana Islam dan politik itu mesti dikaitkan secara tepat. ${ }^{3}$

Dalam lokus kehidupan politik kenegaraan, tertangkap fenomena kecanggungan umat Islam untuk memecahkan persoalan-persoalan fundamental, seperti bagaimana mencari kaitan yang pas antara Islam dan

\footnotetext{
${ }^{1}$ Abd Moqsith Ghazali, "Menolak Islam Politik” dalam Jurnal Tashwirul Afkar: Jurnal Reflekesi Pemikiran Keagamaan dan Kebudayaan, Edisi 12 (Jakarta: LAKPESDAM NU, 2002), 174.

${ }^{2}$ Untuk melengkapi argumen di atas, berikut kutipan statement afirmatif dari sejumlah orientalis yang mengiyakan relasi Islam dan politik. Dr. V. Fitzgerald dalam "Muhammedan Law" berkata, "Islam bukanlah semata agama (a religion), namun ia juga merupakan sebuah sistem politik. (a political system). Meskipun pada dekade-dekade terakhir ada beberapa kalangan dari umat Islam, yang mengklaim diri mereka sebagai kalangan modernis, yang berusaba memisabkan kedua sisi itu, namun seluruh gugusan pemikiran Islam dibangun di atas pondasi babwa kedua sisi itu saling bergandengan dengan selaras, yang tidak dapat dapat dipisabkan satu sama lain." Prof. C. A. Nallino seperti dikutip oleh Sir. T. Arnold dalam bukunya "The Caliphate" berkata, "Muhammad telah membangun dalam waktu bersamaan: agama (a religion) dan negara (a state). Dan batas-batas teritorial negara yang ia bangun itu terus terjaga sepanjang bayatnya."Dr. Schacht mengemukakan dalam Encyclopedia of Social Sciences, "Islam lebih dari sekadar agama: ia juga mencerminkan teori-teori perundang-undangan dan politik. Dalam ungkapan yang lebih sederbana, ia merupakan sistem peradaban yang lengkap, yang mencakup agama dan negara secara bersamaan." Prof. Gibb menyatakan dalam "Mubammedanism”, "Dengan demikian, jelaslab bahwa Islam bukanlah sekadar kepercayaan agama individual, namun ia meniscayakan berdirinya suatu bangunan masyarakat yang independen. Ia mempunyai metode tersendiri dalam sistem kepemerintahan, perundang-undangan dan institusi." Lihat Muhammad Dhiya' al-Din Ra'is, Teori Politik Islam (Jakarta: Gema Insani Press, 2001), 5 - 6.

${ }^{3}$ Bahtiar Efendi, Islam dan Negara: Tranformasi Pemikiran dan Praktik Politik Islam di Indonesia (Jakarta: Paramadina, 1998), 11.
} 
politik; bagaimana memposisikan syariat Islam dalam konteks negara modern demokratis; dan bagaimana syariat Islam itu mesti dipahami dan dipraktikkan. Kecanggungan-kecanggungan ini kemudian berimplikasi pada lahirnya berbagai jenis eksperimentasi politik. Secara kategorial, para pemikir Muslim terfragmentasi ke dalam tiga kelompok. ${ }^{4}$ Kelompok pertama dengan gigih menginginkan diwujudkannya syariat Islam dalam kehidupan berbangsa dan bernegara melalui pranata negara, misalnya dalam bentuk perundang-undangan, peraturan pemerintah, dan sebagainya. Masuk dalam kelompok ini adalah Muhammad 'Abduh, Muhammad Rashid Rida, Hasan al-Banna, Abu al-A'la al-Mawdudy, dan Rashid alGannushy. ${ }^{5}$

Kelompok berikutnya memandang bahwa hubungan agama dengan masalah politik-kenegaraan adalah persoalan etika (moral). Islam tidak menginginkan pemisahan agama dari politik karena agama diperlukan untuk memperbaiki dan memperhalus politik, serta membimbing para pemimpin menuju kemaslahatan warga. Kelompok ini menganggap bahwa negara

${ }^{4}$ Kategorisasi ini tidak dimaksudkan untuk membuat kotak-kotak yang ketat, tetapi hanya sekadar upaya untuk memahaminya dalam konteks sosiologi pemikiran masing-masing. Periksa M. Yusuf Wijaya, "Visi-Visi Pemikiran Keislaman: Upaya Klasifikasi Pemikiran Keislaman Timur Tengah" dalam Islam Garda Depan: Mosaik Pemikiran Islam Timur Tengah, ed. M. Aunul Abied Shah et. al. (Bandung: Mizan, 2001), 38.

${ }^{5}$ Nama-nama yang masuk dalam kelompok ini meski memiliki visi pemikiran yang searah, namun tidak berarti identik dalam seluruh produk pemikiran partikularnya. Sebagai contoh, 'Abduh dan Rida yang sama-sama mengusung frase, din wa shar', serta mengakui perlunya kepemimpinan dan kekuasaan politik karena manusia memiliki kecenderungan negatif untuk mengabaikan ajaran agama apabila tidak ditopang dengan otoritas dan kepemimpinan, menekankan pentingnya legislasi (pembuatan hukum) oleh manusia dan perlunya pengembangan mekanisme yang menopangnya. Hasan al-Banna, meski juga menekankan keharusan membentuk pemerintahan Islam, namun ia tidak menekankan dinamisme hukum dan tugas legislasi dalam pemerintahan dan negara Islam, karena syariat dipandangnya sebagai sistem hukum yang sudah lengkap dan terperinci. Lain halnya dengan Rashid al-Gannushy yang berpandangan bahwa pembentukan negara Islam merupakan tujuan jangka panjang. Sebelum tujuan jangka panjang tercapai, umat Islam dapat berpartisipasi dalam suatu pemerintahan bukan Islam dalam rangka membangun sistem pemerintahan pluralis yang memberikan kekuasaan pada partai mayoritas. Aliansi seperti ini perlu untuk meredam agresi penguasa dan menghindari kediktatoran. Dalam hal ini, partisipasi dalam aliansi politik adalah prasyarat yang termasuk kategori kewajiban keagamaan dalam rangka transisi menuju pemerintahan Islam yang demokratis. Lihat elaborasi selengkapnya dalam "Entri Islam dan Negara”, Ensiklopedi Tematis Dunia Islam (Jakarta: PT Ichtiar Baru Van Hoeve, 2002), 65. 
Madinah adalah model negara demokratis yang genuine, dan Nabi Muhammad adalah seorang demokrat yang sejati dan otentik. Tokoh-tokoh yang berhaluan seperti ini, antara: Ahmad Amin, Muhammad Husayn Haykal, Fazlur Rahman, Robert N. Bellah, Nurcholish Madjid, Amin Rais, dan Jalaluddin Rahmat. ${ }^{6}$ Kelompok ketiga menolak penerapan syariat dan pembentukan negara Islam. Bagi mereka, Islam adalah agama, bukan negara (al-Islam din la dawlab). Lebih lanjut, mereka menampik idealisasi politik Nabi di Madinah. Para pemikir yang berada dalam spektrum pemikiran ini, antara lain: 'Ali 'Abd al-Raziq, Qamaruddin Khan, Muhammad Ahmad Khalfallah, Faraj Faudah, dan Abdurrahman Wahid. ${ }^{7}$

Di kalangan mufassirun juga terdapat kecenderungan untuk berbicara dalam lapangan politik. Ibn Jarir al-Tabary (wafat $310 \mathrm{H}$ ) dalam Tafsir alThabary misalnya banyak berbicara tentang kepala negara dalam kaitannya dengan kesejahteraan rakyat. ${ }^{8}$ Mufassir lain adalah Abu Qasim Muhammad ibn 'Umar al-Zamakhshary (467 - 538 H/1027 - 1144 M) dalam Tafsir alKashshaf. Dia banyak menguraikan tentang negara moral dalam kaitannya dengan eksistensi imamah dalam menolak kezaliman. ${ }^{9}$ Selanjutnya adalah Abu 'Abd Allah Muhammad ibn Ahmad al-Qurtuby (wafat $671 \mathrm{H}$ ) dalam

${ }^{6}$ Abd Moqsith, "Menolak Politik Islam", 175.

${ }^{7}$ Qamaruddin Khan (cendekiawan Pakistan, lulusan Universitas Aligarh) berpandangan bahwa tidak ada teori tentang negara di dalam al-Quran. Nabi Muhammad SAW memang menegakkan "rezim politik", tetapi hal itu merupakan peristiwa insidental yang terkait dengan situasi kesejarahan, bukan tujuan asasi misi kerasulannya. Pendapat senada dilontarkan oleh Muhammad Ahmad Khalfallah yang berpendapat bahwa Islam adalah agama, bukan negara (al-Islam din la dawlab). Maksudnya, asas pembentukan negara ialah keharusan yang bersumber dari kehidupan sosial yang pengelolaannya diserahkan oleh agama kepada masyarakat, bukan teks Ilahi yang diturunkan dalam al-Quran. Penolakan terhadap gagasan negara Islam, atau Islam sebagai agama dan negara juga diberikan Faraj Faudah, pengkritik pedas penerapan syariat di Mesir. Faudah menganut prinsip pemisahan politik dari agama, antara negara dan Islam. Bahkan, dalam pandangannya, pembedaan ini perlu dilakukan demi kebaikan agama dan negara (pemerintahan). Agama terhindar dari manipulasi politik, dan pemerintahan terlaksana tanpa beban yang bersumber dari partikularisme keagamaan. Baca uraian selengkapnya Qamaruddin Khan, Political Concept in The Qur'an (Lahore: Islamic Book Foundation, 1982), 75-76. Bandingkan dengan Muhammad Ahmad Khalfallah, al-Qur'an wa al-Dawlah (Kairo: Maktabah al-Anjalu al-Misriyyah, 1973).

${ }^{8}$ Lihat Abu Ja'far Muhammad ibn Jarir al-Tabary, Tafsir al-Thabary (Beirut: Dar al-Fikr, 1978), 97.

${ }^{9}$ Lihat Abu Qasim Jar Allah Mahmud ibn 'Umar al-Zamakhshary, Tafsir al-Kashshaf Juz III (Mesir: Musthafa al-Babi al-Halabi, tt.), 372. 
Tafsir al-Qurthuby yang banyak berbicara tentang imamah dalam konteks hukum fiqh. ${ }^{10}$ Berikutnya Abu Fida Ismail ibn Kathir al-Dimashqy (wafat $774 \mathrm{H}$ ) dalam Tafsir Ibn Kathir yang banyak mengupas tentang konsep imamah dengan argumentasi rasional. ${ }^{11}$

Salah seorang mufassir yang juga berbicara tentang pemikiran politik Islam adalah Muhammad ibn 'Ali Muhammad ibn 'Abd Allah al-Shawkany. ${ }^{12}$ Lebih jauh, pemikiran politik al-Shawkany dalam Tafsir Fath al-Qadir telah diteliti oleh Ahmad Fahmy Arief dalam disertasi yang ditulisnya tahun 1997 untuk menyelesaikan Program Doktor dalam Ilmu Agama Islam di Institut Agama Islam Negeri (IAIN, sekarang UIN) Syarif Hidayatullah Jakarta dengan judul "Pemikiran Politik dalam Tafsir Fath al-Qadir". ${ }^{13}$ Adapun makalah ini ditulis dengan tujuan untuk me-review disertasi Arief tersebut.

Sebelum melakukan elaborasi lebih jauh, perlu dipertegas terlebih dahulu bahwa istilah pemikiran politik yang dimaksudkan Arief dalam penelitian ini ialah gagasan-gagasan tentang ketatanegaraan. ${ }^{14}$ Gagasangagasan tentang ketatanegaraan ini dibatasi pada konsep kepemimpinan dan musyawarah, konsep hak warganegara untuk memperoleh keadilan, dan konsep hak warganegara untuk hidup berserikat dan berkumpul. Penelitian ini adalah penelitian kepustakaan (Jibrary research). Sehubungan dengan sumber data penelitian ini adalah ayat-ayat al-Quran dan berfokus pada sebuah tema, maka penelitian ini termasuk kajian tafsir dengan

${ }^{10}$ Lihat Abu 'Abd Allah Muhammad ibn Ahmad Al-Qurtuby, al-Jami' li Abkam alQur'an (Beirut: Dar al-Kutub al-'Ilmiyyah, 1993).

${ }^{11}$ Lihat Abu Fida Ismail ibn Kathir al-Dimashqy, Tafsir Ibn Kathir Juz IV (Mesir: Dar Ihya' al-Kutub al-'Arabiyyah, tt.), 32.

${ }^{12}$ Lihat Muhammad ibn 'Ali Muhammad al-Shawkany, Tafsir Fath al-Qadir (Mesir: Dar al-Fikr, 1973).

${ }^{13}$ Ahmad Fahmy Arief, Pemikiran Politik dalam Tafsir Fath al-Qadir (Disertasi, IAIN Syarif Hidayatullah Jakarta, 1997).

${ }^{14}$ Pengertian ini merujuk kepada pengertian politik yang berkenaan dengan kekuasaan dan susunan masyarakat, serta pengertian politik yang berkenaan dengan kekuasaan dan konsep negara. Sebagaimana dimaklumi bahwa di dalam ilmu politik terdapat beberapa konsep di mana konsep kekuasaan dan konsep negara merupakan dua konsep yang terpenting. Lihat Deliar Noer, Pengantar ke Pemikiran Politik (Jakarta: Rajawali, 1983), 189. Periksa pula A. Rahman Zainuddin, Kekuasaan dan Negara, Pemikiran Politik. Ibnu Khaldun (Jakarta: PT. Gramedia Pustaka Utama, 1992), 9. 
pendekatan tafsir tematis (tafsir mawdh'iy). Sedangkan pendekatan dan analisis yang digunakan dalam penelitian ini pendekatan dan analisis semantik.

\section{Biografi al-Imam al-Shawkany}

Nama lengkapnya ialah Muhammad ibn 'Ali Muhammad ibn 'Abd Allah al-Shawkany al-Shan'any. Beliau lahir di desa Hijrah Shawkan, Yaman pada hari Senin, 28 Dhulqa'dah $1172 \mathrm{H}$ dan wafat pada hari Selasa, 27 Jumada al-Akhir $1250 \mathrm{H}$ di usia sekitar 78 tahun. ${ }^{15}$ Al-Shawkany dibesarkan di kota San'a, sekarang ibukota Republik Yaman. Beliau pertama-tama menimba ilmu agama dari ayahandanya sendiri, kemudian dari para ulama kenamaan di San'a dan sekitarnya. ${ }^{16}$ Selanjutnya beliau aktif mengajarkan ilmunya. Di antara sekian banyak muridnya tercatat nama anaknya sendiri yang bernama 'Ali ibn Muhammad al-Shawkany. Puteranya yang masih belia ini dikenal sebagai anak yang saleh dan menguasai berbagai cabang ilmu pengetahuan. ${ }^{17}$

Karena keluasan ilmu pengetahuan dan kedalaman wawasannya, alSyawkani pada zamannya dijuluki sebagai lautan ilmu yang tidak bertepi (bahr al-ulum), matahari pengetahuan (shams al-fubum), Shaikh al-Islam, Qadhy al-Qudhat, dan lain sebagainya. Beliau dikenal sebagai ulama yang menguasai berbagai cabang ilmu pengetahuan agama, seperti tafsir, hadis, fikih, ushul fikih, sejarah, ilmu kalam, filsafat, balaghah, mantiq, dan lain sebagainya. Al-Shawkany tidak hanya mengamalkan ilmu-ilmunya dengan cara

${ }^{15}$ Al-Shawkany, Tafsir Fath al-Qadir Juz I, 4-8.

${ }^{16} \mathrm{Di}$ antara ulama tersebut adalah al-Sayyid al-'Allamah 'Abd al-Rahman ibn Qasim alMadani, al-'Allamah Ahmad ibn 'Amir al-Hada'i, al-'Allamah Ahmad ibn Ahmad al-Harazi, alSayyid al-'Allamah Isma'il ibn al-Hasan ibn Ahmad ibn al-Hasan ibn Imam al-Qasim ibn Yahya al-Khawlani, al-Sayyid al-'Allamah Abd Allah ibn al-Husayn ibn 'Ali ibn al-Imam alMutawakkil 'Ala Allah, al-'Allamah al-Hasan ibn Isma'il al-Maghribi, al-Sayyid al-Imam 'Abd al-Qadir ibn Ahmad, al-'Allamah Hadi ibn Husayn al-Qarini, al-'Allamah 'Abd al-Rahman Hasan al-Akwa', al-Sayyid al-'Allamah 'Ali ibn Ibrahim ibn Ahmad ibn 'Amir, al-Sayyid al-'Arif Yahya ibn Muhammad al-Hautsi dan masih banyak yang lain. Lihat Al-Shawkany, Tafsir Fath alQadirJuzI, 4-8.

${ }^{17}$ Muridnya yang lain adalah al-Allamah Husayn ibn Muhsin al-Sab’i al-Anshari alYamini, Muhammad ibn Hasan al-Syajani al-Zimari, al-'Allamah al-Syaikh 'Abd al-Haqq ibn Fadhal al-Hindi, al-Sharif al-Imam Muhammad ibn Nashir al-Hazimi dan masih banyak lagi yang lain. Lihat Al-Shawkany, Tafsir Fath al-Qadir Juz I, 4-8. 
mengajar, namun juga dituangkannya dalam berbagai karya tulis. Tercatat sebanyak 18 buah karya tulisnya yang diterbitkan dalam bentuk buku dan 146 buah karya tulisnya yang lain dalam wujud manuskrip. Karya-karya tulis utama dari al-Shawkany, antara lain: kitab Tafsir Fath al-Qadir, kitab Nayl al-Afthar, kitab Tubfat al-Dhakirin, dan masih banyak lagi yang lain. ${ }^{18}$ Hampir semua karya tulis al-Shawkany diselesaikan sebelum usia 36 tahun. Produktivitasnya mulai berkurang sejak dia diangkat sebagai hakim di San'a pada masa pemerintahan al-Imam al-Manshur 'Ali ibn 'Abbas (1775 - 1809 M). Pada masa pemerintahan al-Mahdi 'Abd Allah (1815 - 1835 M), alShawkany menjabat sebagai Menteri Dalam Negeri dan Menteri Luar Negeri. ${ }^{19}$

Kitab Tafsir Fath al-Qadir yang akan ditelaah ini terdiri dari lima jilid. Kitab ini memiliki dua keistimewaan. Pertama, uraiannya menggabungkan antara metode riwayah dan metode dirayah. Diidentifikasi riwayah, karena tafsir ini menggunakan ayat-ayat al-Qur'an, hadis-hadis Rasul SAW, dan pendapat para sahabat dalam menjelaskan isi kandungan ayat-ayat al-Quran. Diidentifikasi dirayah, karena tafsir ini menggunakan kaidah-kaidah kebahasaan dalam menganalisis ayat-ayat al-Quran. ${ }^{20}$

Keistimewaan keduanya ialah, kitab ini ditulis oleh seorang ulama Shi'ah Zaydiyyah, yaitu al-Imam al-Shawkany. Sekte ini disebut dengan Shi'ah Zaydiyyah karena pengikut sekte ini berpegang teguh kepada ajaran-ajaran

\footnotetext{
${ }^{18}$ Karya-karya tulisnya yang lain adalah kitab Irshad al-Siqat ila Ittifaq al-Shara'i 'ala alTawhid wa al-Ma'ad wa al-Nubuwwah, kitab al-Thawd al-Munif fi al-Intishaf li al-Sa'd min al-Sharif, kitab Thayyib al-Nashrfi al-Masa'il al-'Ashr, kitab Fi Ikbtilaf al- 'Ulama' fi Taqdir Muddat al-Nifas, kitab Fi Hadd al-Safar alladhi Yajibu ma'abu Qashr al-Shalat, kitab al-Mukammilah fi al-Basmalah, kitab Fi Anna al-Thalaq la Yatba'u al-Thalaq, kitab Fi Ibthal Da'wah al-Ijma' 'ala Tabrim al-Sama', kitab Bughyah fi Mas'alah al-Ru'yah, kitab Irshad al-Ghaby ila Madhab Ablal-Baytfi Shabb al-Naby, kitab Irshad al-Mustafid ila Daf'i Kalam ibn Daqiq al-Td fi al-Ittilaq wa al-Taqvid, kitab al-Dawa' al-Ajil li Daf'i al-'Aduw al-Sa'il, kitab 'Ajibah fi Raf'i al-Mazalim wa al-Ma'asim, kitab al-Durr al-Nadid fi Ikblas Kalimah al-Tawhid, kitab Fi Wujub Tawhid Allah 'Azza wa Jalla, kitab al-Maqalah al-Fakhirah, kitab Nuqlab al-Abdaq fi 'Ilm al-Istiqaq, kitab Raf' al-Raybah fi ma Yajuzu wa ma la Yajuzu min alGhibah, kitab Kashf al-Astar 'an Hukm al-Shaf'ah bi al-jiwar, kitab Washiyyu al-Marqum fi Tabrim al-Tahalli bi al-Dhahab li al-Rijal 'ala al-'Umum, kitab Fi Hukm al-Tas'ir, kitab Nashr al-Jawhar fi Sharh Hadith Abi al-Dhar, kitab Tanbih al-Amthal 'ala Jawaz al-Isti'anah min Khalish al-Mal, dan lain sebagainya. Lihad Al-Shawkany, Tafsir Fath al-Qadir Juz. I, 4-8.

${ }^{19}$ Lihat Al-Shawkany, Tafsir Fath al-Qadir Juz I, 4-8.

${ }^{20}$ Muhammad Husayn al-Zahabi, al-Tafsir wa al-Mufassirun Juz. I (Mesir: Dar al-Kutub al-Misriyyah, 1976), 152.
} 
yang dikembangkan oleh al-Imam Zaid ibn 'Ali ibn Husayn ibn 'Ali ibn 'Abi Thalib. ${ }^{21} \mathrm{Di}$ antara ajaran sekte ini adalah imam afdhal. Menurut pengikut sekte ini, 'Ali ibn Abi thalib lebih afdhal (utama) daripada Abu Bakr al-Shiddiq. Namun demikian dalam teologi sekte Zaydiyyah tetap mengakui kekhalifahan Abu Bakr al-Shiddiq, 'Umar ibn al-Khattab, dan 'Usman ibn 'Affan. Tetapi yang lebih afdhal adalah 'Ali ibn Abi Thalib, sedangkan tiga khalifah pendahulunya disebut oleh mereka dengan imam mafdhul.22

\section{Pemetaan Pemikiran Politik dalam Tafsir Fath al-Qadir}

Masalah pokok penelitian ini ialah bagaimana pemikiran politik dalam kitab Tafsir Fath al-Qadir. Untuk memperoleh jawaban yang jelas dari masalah pokok di atas, maka sub-sub masalah dipetakan sebagai berikut: bagaimana konsep kepemimpinan dan musyawarah menurut kitab Tafsir Fath al-Qadir, bagaimana hak warganegara untuk memperoleh keadilan menurut kitab Tafsir Fath al-Qadir, dan bagaimana konsep hak warganegara untuk hidup berserikat dan berkumpul menurut kitab Tafsir Fath al-Qadir.

\section{Tafsir Ayat-ayat al-Quran yang Berkaitan dengan Kepemimpinan dan Musyawarah menurut Kitab Tafsir Fath al-Qadir}

Sebelumnya perlu ditegaskan terlebih dahulu bahwa yang dimaksud dengan terma pemimpin di sini adalah pemegang kendali kekuasaan dalam kaitannya dengan kenegaraan. Adapun yang dimaksud dengan terma musyawarah di sini ialah proses bertukar pendapat untuk memperoleh kebenaran. ${ }^{23}$ Secara terinci dalam sub pembahasan ini akan diuraikan konsep pemikiran politik al-Shawkany tentang kepemimpinan dan musyawarah, syarat-syarat seorang pemimpin, loyalitas rakyat kepada pemimpin, kewajiban pemimpin untuk melindungi hak-hak rakyat serta etik musyawarah dalam Islam.

${ }^{21}$ Ali Musthafa al-Ghuraby, al-Firaq al-Islamiyyah wa Nash'ah Ilm al-Kalam 'inda al-Muslimin (Mesir: Muhammad 'Ali Shahib, tt.), 289.

${ }^{22} \mathrm{Ahmad}$ al-Shahrastany, al-Milal wa al-Nihal (Beirut: al-Ma'arif, t.t.), 154.

${ }^{23}$ Abdul Mun'im Salim, Konsepsi Kekuasaan Politik dalam al-Quran (Jakarta: Raja Grafindo Persada, 1994), 231. 
Menurut al-Shawkany, al-Quran menggunakan terma khalifah, ${ }^{24}$ ulu al-amri, ${ }^{25}$ imam dan malik untuk pengertian pemimpin. ${ }^{26}$ Terma khalifah secara umum berarti pengganti kedudukan kepemimpinan $\mathrm{Nabi}^{27}$ secara khusus berarti kepala pemerintahan umat Islam. ${ }^{28}$ Terma ulu al-amri diartikan sebagai institusi kepemimpinan yang terdiri dari para imam, sulthan, hakim dan tokoh-tokoh pemegang kekuasaan berdasarkan syariat Islam. ${ }^{29}$ Terma imam diartikan sebagai pemimpin umat Islam yang dapat diteladani dan dijadikan sebagai contoh kehidupan duniawi dan ukhrawi. ${ }^{30}$ Terma malik diartikan sebagai orang yang memiliki wewenang untuk mengatur pemerintahan. Kewenangan itu diperolehnya melalui suksesi turun temurun. ${ }^{31}$

Menurut al-Shawkany, syarat-syarat seseorang untuk menjadi pemimpin menurut al-Quran ialah yang bersangkutan harus benar-benar beriman kepada Allah SWT dan dibuktikan dengan sepak terjang seharihari, memiliki ilmu pengetahuan yang luas dan berbadan sehat. Orang kafir dan munafiq tidak dibenarkan tampil sebagai pemimpin umat Islam. ${ }^{32} \mathrm{Pada}$ dasarnya seorang pemimpin itu harus ditaati oleh rakyatnya. Tetapi ketaatan kepada seorang pemimpin tidak berlaku, apabila pemimpin yang bersangkutan berbuat melampaui batas, yaitu berlaku syirik kepada Allah SWT.

Seorang pemimpin, menurut al-Shawkany, wajib melindungi kepentingan rakyat, terutama yang menyangkut lima kepentingan pokok (mabadi' khamsah)-nya. Kelima kepentingan itu ialah: agama, jiwa, keturunan, harta dan akal. Rakyat berhak menuntut perlindungan menyeluruh atas lima kepentingan pokok tersebut kepada pemimpin. ${ }^{33}$

\footnotetext{
${ }^{24}$ Kata khalifah dalam al-Quran ditemukan di 6 tempat: Q.S. 2:30; 39:26; 6:165; 10:73; 27;62; dan 58:7.

${ }^{25}$ Kata ulu al-amri ditemukan di 2 tempat: Q.S. 4:59 dan 4:83.

${ }^{26}$ Adapun kata imam ditemukan dalam Q.S. 2:124, sedangkan kata malik dalam Q.S. $2: 247$

${ }^{27}$ Arief, Pemikiran Politik, 78.

${ }^{28}$ Arief, Pemikiran Politik, 78.

${ }^{29}$ Arief, Pemikiran Politik, 89 - 92.

${ }^{30}$ Arief, Pemikiran Politik, $92-93$.

${ }^{31}$ Arief, Pemikiran Politik, 93 - 94.

${ }^{32}$ Arief, Pemikiran Politik, 78.

${ }^{33}$ Arief, Pemikiran Politik, 88.
} 
Terma mushawarah oleh al-Shawkany diartikan saling memberi dan saling mengambil pendapat dalam suatu pertemuan. Dalam proses bertukar pendapat itu, akan diperoleh mutiara-mutiara berharga dan pikiran-pikiran cemerlang yang mungkin tidak didapatkan dalam berfikir sendirian. Unsurunsur etika yang harus diperhatikan dalam mushawarah ialah menghargai pimpinan mushawarah dan menghargai pendapat orang lain. Setiap anggota mushawarah harus meminta izin kepada pimpinan mushawarah untuk berbicara dan untuk keperluan lainnya. Setiap anggota mushawarah harus menghargai pendapat orang lain, terlepas dari bagus-tidaknya pendapat tersebut. ${ }^{34}$

Menurut al-Shawkany, pimpinan mushawarah mempunyai kewenangan untuk mengatur jalannya mushawarah. Keputusan untuk memberi izin kepada anggota mushawarah yang mempunyai keuzuran untuk meninggalkan mushawarah, atau memperkenankan atau menolak permohonan anggota mushawarah untuk angkat bicara, tergantung pada situasi dan kondisi. Materi-materi yang dimusyawarahkan, menurut al-Shawkany, meliputi masalah-masalah umum yang menyangkut perang dan damai, yang menyangkut kesejahteraan dan kemaslahatan orang banyak, dan lain sebagainya yang tidak diatur oleh wahyu dan sunnah Rasul Allah SAW. Adapun masalah-masalah yang sudah jelas petunjuknya dalam wahyu dan sunnah Rasul Allah SAW, tidak perlu dimusyawarahkan lagi.

\section{Tafsir Ayat-ayat al-Quran yang Berkaitan dengan Hak Warga Negara untuk Memperoleh Keadilan menurut kitab Tafsir Fath al-Qadir}

Al-Quran menggunakan terma al-'adl dan al-qisth untuk pengertian keadilan. Menurut al-Shawkany, terma al-'adl diartikan sebagai keadilan distributif, yaitu suatu pandangan yang menitikberatkan kepada persamaan, tidak berat sebelah, dan tetap berada di tengah-tengah. ${ }^{35}$ Adapun terma al-qisth diartikan sebagai keadilan proporsional, yaitu suatu pandangan yang menitikberatkan kepada penempatan sesuatu sesuai dengan proporsinya dan pemenuhan hak seseorang sesuai dengan proporsinya. ${ }^{36}$

\footnotetext{
${ }^{34}$ Arief, Pemikiran Politik, 97 - 103.

${ }^{35}$ Arief, Pemikiran Politik, 130.

${ }^{36}$ Arief, Pemikiran Politik, 129.
} 
Menurut al-Shawkany, keadilan ilahiyah ialah suatu pandangan yang menitikberatkan kepada loyalitas manusia sebagai makhluk ciptaan Allah SWT kepada Yang Maha Kuasa. Pada sisi ini keadilan identik dengan penyerahan diri sepenuhnya kepada kekuasaan Allah SWT. Inti dari keadilan ilahiyah ini ialah pengakuan bahwa tidak ada Tuhan yang patut disembah dengan sebenarnya selain Allah SWT. ${ }^{37}$

Menurut al-Shawkany, terdapat perbedaan antara keadilan ( $a l$-'adl), kebajikan (al-ihsan), dan kejahatan (al-sharr). Apabila pemberian balasan melebihi porsinya, maka disebut dengan al-ihsan. Sedangkan jika kurang dari porsinya, maka disebut dengan al-sharr. Prinsip-prinsip keadilan itu, menurutnya, bertumpu pada rakyat, dalam hal ini pada unsur manusia sebagai orang yang diperintah. Rakyat mempunyai persamaan hak di hadapan undang-undang Allah SWT. Tidak boleh ada perbedaan di antara mereka, semuanya diperlakukan sama di hadapan Allah SWT. ${ }^{38}$

\section{Tafsir Ayat-ayat al-Quran yang Berkaitan dengan Hak Warga Negara untuk Hidup Berserikat dan Berkumpul menurut kitab Tafsir Fath al-Qadir}

Menurut al-Shawkany, untuk hidup berserikat dan berkumpul, maka yang perlu dibina adalah persaudaraan yang berdasarkan ajaran Islam. Persaudaraan itu identik dengan keimanan. Berbagai pertengkaran dan perselisihan yang terjadi di antara sesama mukmin, penyelesaiannya adalah kembali kepada ajaran Islam itu sendiri. Penekanan penyelesaiannya itu diarahkan kepada penyadaran pada tiap-tiap individu bahwa mereka itu berasal dari keturunan (dhurriyyah) yang sama, yaitu Nabi Adam AS dan isterinya Hawwa. ${ }^{39}$

Dalam realitas kehidupan, keragaman ras, suku dan adat istiadat tidak dapat dihindari. Kendati berbeda-beda dalam suku, ras dan kebiasaan, namun komunitas masyarakat itu dapat diikat dengan agama yang satu, yaitu Islam. Di dalam Islam, tidak ada perbedaan suku, ras dan kebiasaan, semuanya dipandang sama di hadapan Allah SWT.

\footnotetext{
${ }^{37}$ Arief, Pemikiran Politik, 131.

${ }^{38}$ Arief, Pemikiran Politik, 129 - 130.

${ }^{39}$ Arief, Pemikiran Politik, 176.
} 
Perselisihan dan pertengkaran yang terjadi di antara sesama mukmin, menurut al-Shawkany, harus segera didamaikan. Penyelesaian yang berlarutlarut dapat mengakibatkan retaknya persaudaraan yang pada gilirannya akan membawa kepada robohnya keutuhan bangsa dan negara. Jangan sampai terjadi hanya karena persoalan-persoalan kecil akan membawa kepada rapuhnya tali silaturahmi antara sesama mukmin..$^{40}$

Menurutnya, dalam kelompok besar yang terdiri dari banyak suku, ras dan adat istiadat, maka tidak tertutup kemungkinan adanya sikap saling berbangga antarkelompok. Jika terjadi sikap saling membanggakan kelompoknya masing-masing, maka akan terjadi saling menghina satu terhadap yang lain. Dalam hal ini al-Shawkany menekankan kepada mereka yang saling berbangga dan saling menghina tadi untuk merenungkan terma (ÚÓi), yang artinya ialah boleh jadi. Dengan resep tersebut, potensi saling menghina satu sama lainnya dapat diredam. Terma di atas menyadarkan mereka yang bertikai bahwa boleh jadi yang dihina lebih baik dari mereka yang menghina. ${ }^{41}$

\section{Pembacaan Kritis atas Pemikiran Politik al-Shawkany}

\section{Antara Political Theology dan Political Philosophy}

Kajian tentang politik secara garis besar, menurut Leo Strauss, dapat diklasifikasikan menjadi dua: political theology dan political philosophy. Yang pertama adalah studi atas ajaran-ajaran politik berdasarkan wahyu Tuhan. Di Abad Pertengahan, misalnya, yang dikembangkan adalah political theology. Sedangkan yang kedua ini adalah studi tentang pemikiran atau filsafat politik. Dan, ini adalah cabang dari filsafat sehingga tekanannya lebih kepada pemikiran. ${ }^{42}$

Hamid Enayad, seorang intelektual Muslim asal Iran dalam bukunya yang berjudul Modern Islamic Political Thought, mengatakan bahwa dalam tradisi Islam pemikiran filsafat politik tidak berkembang karena pemikiran

${ }^{40}$ Arief, Pemikiran Politik, 178 - 180.

${ }^{41}$ Arief, Pemikiran Politik, 184.

${ }^{42}$ Transkrip Diskusi Buku “Asas Moral dalam Politik" (Moral Foundation of Politics), 11 April 2006. www.freedominstitute.com. 
politik diajarkan dalam 2 disiplin yang berbeda, yakni disiplin fikih dan disiplin filsafat. Ironisnya, dalam tradisi keilmuan Islam yang mendominasi adalah disiplin fikih, karenanya tidak bisa keluar dari paradigma political theology (teologi politik). ${ }^{43}$ Dalam konteks ini, penulis ingin memberikan kritik kepada al-Shawkany (sebagai penulis Tafsir Fath al-Qadir), sekaligus kepada Ahmad Fahmy Arief yang mencoba mengidentifikasi ajaran-ajaran politik dalam kitab tafsir yang ditulis pada abad $13 \mathrm{H}$ tersebut.

Dalam analisis penulis, al-Shawkany jelas berangkat dari paradigma teologi politik. Selain karena memposisikan diri sebagai "penafsir" wahyuwahyu Tuhan (baca: al-Quran), teramati secara jelas bahwa al-Shawkany memiliki preferensi kuat pada perspektif fikih dalam mengupas ayat-ayat politik al-Quran. Adalah mengherankan, al-Shawkany $(1172 \mathrm{H}-1250 \mathrm{H})$ yang hidup pasca Abad Pencerahan (meminjam istilah Barat) tetap menampilkan diri sebagai sosok pemikir yang konservatif. Telah menjadi mafhum bahwa di Abad Pertengahan teori dan ruang politik didominasi oleh teologi agama. Dalam ungkapan yang lebih lugas, legitimasi politik selalu meniscayakan adanya legitimasi doktrin agama. Namun seiring dengan hadirnya para pemikir politik modern—seperti: Machiavelli, Hobbes, Descartes, dan lain-lain, tampak ada transformasi yang massif. Misalnya, legitimasi bukan lagi menjadi hak agama, melainkan rakyat (publik).

Meski demikian, ada titik di mana kita dapat memahami "pilihan" ajaran politik al-Shawkany. Secara akademis, al-Shawkany dibesarkan oleh tradisi keilmuan negeri Yaman, yang secara intelektual nyaris tidak memiliki kontak dengan tradisi keilmuan Barat. Berbeda dengan Mesir misalnya, yang sejak invasi Napoleon Bonaparte di akhir Abad 18 telah berinteraksi dengan Eropa. Keterputusan dialog intelektual inilah yang mencetak al-Shawkany menjadi seorang konservatif yang setia terhadap tradisi (baca: agama).

Terkait dengan kesimpulan penulis bahwa perspektif tafsir alShawkany itu cenderung fiqh oriented, di sini dapat dikemukakan sejumlah dalil. Di antaranya tentang persyaratan seseorang untuk menjadi pemimpin.

${ }^{43}$ Masih menurut Enayat, dalam Islam sebenarnya ada tradisi pemikiran politik yang sangat maju dan liberal. Misalnya adalah pemikiran Al-Farabi, Ibn Sina, Ibn Rusyd dan lainlain. Namun sekali lagi kesemuanya itu menjadi mandeg karena kajian politik Islam lebih berorientasi pada fikih. 
Menurut al-Shawkany, yang bersangkutan harus benar-benar beriman kepada Allah SWT dan dibuktikan dengan sepak terjang sehari-hari, memiliki ilmu pengetahuan yang luas, dan berbadan sehat. Orang kafir dan munafiq tidak dibenarkan tampil sebagai pemimpin umat Islam. ${ }^{44}$ Contoh lainnya adalah soal materi-materi yang dapat dimusyawarahkan. Menurut al-Shawkany, hanya meliputi masalah-masalah umum yang menyangkut perang dan damai, yang menyangkut kesejahteraan dan kemaslahatan orang banyak, dan lain sebagainya yang tidak diatur oleh wahyu dan sunnah Rasul Allah SAW. Adapun masalah-masalah yang sudah jelas petunjuknya dalam wahyu dan sunnah Rasul Allah SAW, tidak perlu dimusyawarahkan lagi. ${ }^{45}$ Implikasi dari pendekatan fikih al-Shawkany tersebut, ajaran-ajaran politiknya menjadi beraroma sektarian, atau dalam istilah kontemporernya "Anti Pencerahan".

Untuk Arief yang memberi judul disertasinya dengan "Pemikiran Politik dalam Tafsir Fath al-Qadir", penulis menilainya misleading. Penulis menyebutnya misleading, dikarenakan judul seharusnya adalah "Teologi Politik. dalam Tafsir Fath al-Qadir". Pasalnya, ajaran-ajaran politik yang dikupas alShawkany sangat normatif dengan mengacu secara rigid terhadap dogma dan doktrin agama. Seperti telah disinggung sebelumnya, kajian pemikiran politik itu kental dengan aroma filsafat. Namun yang tersaji dalam Tafsir Fath al-Qadir justru teologi politik yang bernafaskan doktrin-doktrin beku agama. Di sinilah letak kekurangtepatan Arief dalam mengidentifikasi obyek sentral penelitiannya yang penulis istilahkan dengan misleading itu.

\section{Urgensi Aspek Historisitas dalam Kajian Pemikiran}

Di antara tesis yang dipegangi oleh sebagian pengkaji teori-teori politik secara umum, adalah adanya hubungan yang erat antara timbulnya pemikiran-pemikiran politik dengan perkembangan kejadian-kejadian historis. Jika tesis itu benar bagi suatu jenis atau mazhab pemikiran tertentu, dalam bidang pemikiran apapun, hal itu tentunya juga benar bagi pertumbuhan dan perkembangan teori-teori politik Islam. Karena itu keduanya harus dilihat seakan-akan seperti dua sisi mata uang. Atau, dua

${ }^{44}$ Arief, Pemikiran Politik, 78.

${ }^{45}$ Arief, Pemikiran Politik. 
bagian yang saling melengkapi satu sama lain. Sifat hubungan di antara keduanya berubah-ubah: terkadang pemikiran-pemikiran itu tampak menjadi penggerak terjadinya berbagai kejadian, dan terkadang pula kejadian-kejadian itu menjadi pendorong atau rahim yang melahirkan pendapat-pendapat itu. Kadang-kadang suatu teori hanyalah sebuah bias dari kejadian yang berlangsung pada masa lalu. ${ }^{46}$

Karena adanya hubungan antara dua segi ini: segi teoretis dan historis, maka jelaslah masing-masing dari kedua hal itu tidak dapat dipahami tanpa keberadaan yang lain. Pendekatan terbaik untuk mempelajari teori-teori ini adalah dengan mengkajinya sambil menelaah historisitas realitas yang berkaitan dengannya. Sehingga dapat dipahami hakikat hubungan yang mengkaitkan antara dua segi, dapat memperjelas pendapat-pendapat, dan dapat menunjukkan bumi yang menjadi tempat tumbuhnya masing-masing pemikiran hingga berbuah, dan mencapai kematangannya. Inilah pendekatan yang seharusnya digunakan.

Pendekatan studi seperti ini yang tidak tampak dalam penelitian Arief kala meneliti Teologi Politik al-Shawkany dalam kitab tafsirnya Fath alQadir. Implikasinya, kajian Ariefnya terasa kering dan hambar, akibat ketiadaan penjiwaan atas realitas-realitas sejarah yang melingkupi diri Sang Author, al-Shawkany. Dalam ungkapan yang lebih lugas, hal itu menyebabkan teologi politik al-Shawkany dalam kitab tafsirnya menjadi ahistoris, dan dapat dipastikan akan menyusul kegagalan teori-teori politik sebelumnya untuk menjadi alternatif solusi atas kompleksitas problematika politik Islam kontemporer. Sungguh sangat disayangkan.

${ }^{46} \mathrm{Di}$ antara tokoh yang mengatakan hal itu adalah Prof. J.N. Figgis dalam buku "The Divine Right of Kings -yang dengan bukunya itu ia mendapatkan salah satu penghargaan sastra yang besar. Dalam beberapa tempat dari bukunya itu, ia membuktikan bahwa teori itu lahir akibat situasi dan kondisi yang berlangsung pada saat itu. Di antara ungkapannya itu adalah yang ia tulis dalam pendahuluan bukunya itu, "Teori ini lebih tepat dikatakan sebagai akibat dari realitas yang ada, ketimbang sebagai buah pemikiran murni”. J. Matters juga mengatakan dalam bukunya "Concepts of State, Sovereignty and International Law" sebagai berikut, "Ini adalah fakta yang penting, meskipun tidak diketabui oleb banyak orang bahwa teori-teori yang ditelurkan oleb Hocker, Hobbes, Locke, dan Roussou merupakan hasil dari kecenderungan-kecenderungan politik mereka, dan perhatian mereka terbadap hasil peperangan-pepernagan agama dan politik, yang-secara berturut-turutterjadi pada zaman mereka, di negara-negara mereka, atau di negara-negara yang menjadi perbatian mereka". Periksa kembali Rais, Teori Politik Islam, 1 - 2. 


\section{Penutup}

Pemikiran politik yang dimaksudkan dalam penelitian terhadap Tafsir Fath al-Qadirini adalah gagasan-gagasan tentang ketatanegaraan. Gagasangagasan tentang ketatanegaraan ini dibatasi pada konsep kepemimpinan dan musyawarah, konsep hak warganegara untuk memperoleh keadilan, dan konsep hak warganegara untuk hidup berserikat dan berkumpul.

Mengacu kepada klasifikasi Leo Strauss, kajian tentang politik secara garis besar dibagi dua: political theology dan political philosophy. Yang pertama adalah studi atas ajaran-ajaran politik berdasarkan wahyu Tuhan. Sedangkan yang kedua ini adalah studi tentang pemikiran atau filsafat politik. Dan, ini adalah cabang dari filsafat sehingga tekanannya lebih kepada pemikiran. Penulis menilai judul disertasi Arief "Pemikiran Politik dalam Tafsir Fath alQadir" itu misleading. Misleading, dikarenakan judul seharusnya adalah "Teologi Politik dalam Tafsir Fath al-Qadir". Pasalnya, ajaran-ajaran politik yang dikupas al-Shawkany sangat normatif dengan mengacu secara rigid terhadap dogma dan doktrin agama.

Hamid Enayad, dalam bukunya Modern Islamic Political Thought, mengatakan bahwa dalam tradisi Islam pemikiran filsafat politik tidak berkembang karena pemikiran politik diajarkan dalam 2 disiplin yang berbeda, yakni disiplin fikih dan disiplin filsafat. Ironisnya, dalam tradisi keilmuan Islam yang mendominasi adalah disiplin fikih, karenanya tidak bisa keluar dari paradigma political theology (teologi politik). Dalam analisis penulis, al-Shawkany jelas berangkat dari paradigma teologi politik. Selain karena memposisikan sebagai "penafsir" wahyu-wahyu Tuhan (baca: alQuran), teramati secara jelas bahwa al-Shawkany memiliki preferensi kuat pada perspektif fikih dalam mengupas ayat-ayat politik al-Quran [ ]

\section{DAFTAR PUSTAKA}

Al-Dimashqy, Abu Fida Ismail ibn Kathir. Tafsir Ibn Katbir. Mesir: Dar Ihya' al-Kutub al-'Arabiyyah, tt.

Al-Ghuraby, Ali Musthafa. al-Firaq al-Islamiyyah wa Nash'ah 'Tlm al-Kalam inda al-Muslimin. Mesir: Muhammad 'Ali Shahib, tt. 
Al-Qurtubi, Abu 'Abd Allah Muhammad ibn Ahmad. Al-jami' li Abkam al-Qur'an. Beirut: Dar al-Kutub al-'Ilmiyyah, 1993.

Al-Shahrastany, Ahmad. al-Milal wa al-Nihal. Beirut: al-Ma'arif, t.t.

Al-Shawkany, Muhammad ibn 'Ali Muhammad. Tafsir Fath al-Qadir. Mesir: Dar al-Fikr, 1973.

Al-Tabary, Abu Ja'far Muhammad bin Jarir. Tafsir al-Thabary. Beirut: Dar al-Fikr, 1978.

Al-Zahaby, Muhammad Husayn. al-Tafsir wa al-Mufassirun. Mesir: Dar alKutub al-Mishriyyah, 1976.

Al-Zamakhshary, Abu Qasim Jar Allah Mahmud ibn 'Umar. Tafsir alKashshaf. Mesir: Musthafa al-Babi al-Halabi, t.t.

Arief, Ahmad Fahmy. Pemikiran Politik dalam Tafsir Fath al-Qadir. Disertasi, IAIN Syarif Hidayatullah Jakarta, 1997.

Efendi, Bahtiar. Islam dan Negara: Tranformasi Pemikiran dan Praktik Politik Islam di Indonesia. Jakarta: Paramadina, 1998.

"Entri Islam dan Negara". Ensiklopedi Tematis Dunia Islam. Jakarta: PT Ichtiar Baru Van Hoeve, 2002.

Ghazali, Abd Moqsith. "Menolak Islam Politik". Jurnal Tashwirul Afkar: Jurnal Refleksi Pemikiran Keagamaan dan Kebudayaan, Edisi 12. Jakarta: LAKPESDAM NU, 2002.

Khalfallah, Muhammad Ahmad. Al-Quran wa al-Dawlah. Kairo: Maktabah al-Anjalu al-Misriyyah, 1973.

Khan, Qamaruddin. Political Concept in The Qur'an. Lahore: Islamic Book Foundation, 1982.

Noer, Deliar. Pengantar ke Pemikiran Politik. Jakarta: Rajawali, 1983.

Salim, Abdul Mun'im. Konsepsi Kekuasaan Politik dalam al-Quran. Jakarta: Raja Grafindo Persada, 1994. 
Wijaya, M. Yusuf. "Visi-Visi Pemikiran Keislaman: Upaya Klasifikasi Pemikiran Keislaman Timur Tengah". Islam Garda Depan: Mosaik Pemikiran Islam Timur Tengah. Ed. M. Aunul Abied Shah et. al. Bandung: Mizan, 2001.

www.freedominstitute.com. Transkrip Diskusi Buku "Asas Moral dalam Politik" (Moral Foundation of Politics), 11 April 2006.

Zainuddin, A. Rahman. Kekuasaan dan Negara, Pemikiran Politik Ibnu Khaldun. Jakarta: PT. Gramedia Pustaka Utama, 1992. 